\title{
COMPARATIVE VALUES OF DIFFERENT GRADES OF WHEAT OF CROPS OF 1903 AND 1904.
}

\author{
BY R. HARCOURT.
}

Received November 9, 1905 .

THE exact milling value of each grade of wheat is a question which is arousing a great deal of interest in the Canadian Northwest at the present time. The growers feel that the spread in the price paid for the different grades is wider than it should be, and that the appearance of the grain is taken into consideration more than the actual milling value.

With the object of gaining more definite information regarding the justice of the grading done on individual lots of wheat as delivered by the farmer, the Northwest Territorial Department of Agriculture collected and forwarded to us a number of samples of wheat of the different grades of the crops of 1903 and 1904 . A record was kept of the previous cultivation of the ground on which each of the samples was grown. Each sample consisted of approximately eight bushels of wheat. In both years' work, the samples were intended to represent the various grades from No. I Hard to No. 4 Northern, in duplicate. Unfortunately, however, when the various lots of wheat were submitted to the Chief Grain Inspector, Winnipeg, for official grading, the grades were changed as shown in Table I.

All the wheat was received in good condition and was from six to eight months old when milled. The milling was done in a short process mill in Guelph. Every means known to the miller was taken to prevent the mixing of the products of the various lots in the milling process and to insure the whole of the products being recovered. The percentage yield of flour given in the following table represents the total yield. of flour obtained, but Io per cent. of low grade was taken from the portion saved for chemical analysis and for the baking tests. The flour was kept in a dry airy room for nearly three months before the analytical and baking work was done. Unfortunately, no record was kept of the weight of roo grains or of the measured bushels of the various lots of the crop of 1903. The official grading of the samples of both years, the weight of roo kernels, and weight per measured bushel of the sample for the crop of 1904, 
and the percentage yield of flour obtained from the wheat of 1903 and I904 are given in the following table:

Table I.-Showing Grades and Percentage Yield of Flour.

\begin{tabular}{|c|c|c|c|c|c|c|}
\hline \multicolumn{3}{|c|}{ Grade. } & \multirow{2}{*}{$\begin{array}{c}\text { Weight of } \\
\text { I00 kernels. } \\
\text { Ig04. } \\
\text { Grams. }\end{array}$} & \multirow{2}{*}{$\begin{array}{l}\text { Weight per } \\
\text { measured bus. } \\
\text { Igo4. } \\
\text { Lbs. }\end{array}$} & \multicolumn{2}{|c|}{ Percentage of flour } \\
\hline \multicolumn{2}{|c|}{ I903. } & 19904. & & & I903. & $\stackrel{\text { I904. }}{ }$ \\
\hline \multicolumn{2}{|c|}{ I Hard } & I Hard & 3.2527 & 64.0 & 70.8 & 71.9 \\
\hline I & & I " & 3.2854 & 64.0 & 69.8 & 72.0 \\
\hline \multicolumn{2}{|c|}{ I Northern } & I Northern & $3.252 \mathrm{I}$ & 65.0 & 70.0 & 71.8 \\
\hline I & $"$ & “ & 3.3793 & 65.5 & 69.9 & 72.0 \\
\hline 1 & $"$ & " & 3.1531 & 62.5 & 70.7 & 68.3 \\
\hline & & “ & 3.0785 & 61.5 & $\ldots$ & 69.7 \\
\hline 2 & “ & $\ldots$ & $\ldots$ & $\ldots$ & 68.3 & $\ldots$ \\
\hline 3 & " & 3 & 2.9180 & 62.5 & 68.3 & 70.0 \\
\hline 3 & “ & $\ldots$ & $\ldots$ & $\ldots$ & 68.1 & $\ldots$ \\
\hline 3 & “ & $\ldots$ & $\ldots$ & $\ldots$ & 68.2 & $\ldots$ \\
\hline 4 & “ & 4 & 3.1548 & 62.5 & 68.0 & $65 . \mathrm{I}$ \\
\hline & & $" \prime$ & 2.9194 & 60.0 & $\ldots$ & 66.I \\
\hline
\end{tabular}

The third sample of No. I Northern of the crop of I903 was what was called "stook frozen" or "riffled" wheat. This wheat was covered with snow while in the stooks. The melting snow apparently softened the wheat and wrinkled it, thus causing it to be graded lower than it otherwise would have been. The two samples of No. 4 Northern of the crop of 1904 were composed almost entirely of Red Fife and would doubtless have graded No. I Hard or No. I Northern if not frosted. The other samples of the same crop were graded down either because of slight frost or because of the presence of soft grains. One sample was graded as low as No. 5 Northern and has been left out of this report. Millers to whom the samples were shown stated that all the Northern grades were better wheat than they could buy in corresponding grades in Ontario.

In order that the yield of flour obtained by grinding in the large mill might be checked, we sent samples of each lot of wheat of the crop of 1904 to the Columbus Laboratories, Chicago, where they were ground in a small mill especially adapted to determining the yield of flour from comparatively small lots of wheat. The results obtained are embodied in the following table: 
Table II.-Showing Weight Per Measured Bushel and Yield of Flour,

\begin{tabular}{|c|c|c|c|c|c|c|c|c|}
\hline \multirow[b]{2}{*}{ Grade. } & \multicolumn{2}{|c|}{$\begin{array}{l}\text { Weight per measured } \\
\text { bushel. }\end{array}$} & \multicolumn{2}{|c|}{$\begin{array}{l}\text { Yield of flour from } \\
\text { wheat. }\end{array}$} & \multicolumn{4}{|c|}{$\begin{array}{c}\text { Bushels ( } 60 \text { tbs.) to barrel } \\
\text { of flour. }\end{array}$} \\
\hline & $\begin{array}{c}\text { Uncleaned. } \\
\text { Lbs. }\end{array}$ & $\begin{array}{c}\text { Cleaned. } \\
\text { L,bs. }\end{array}$ & $\begin{array}{c}\text { 100 lbs. } \\
\text { uncleaned. }\end{array}$ & $\begin{array}{l}\text { I bushel } \\
\text { clea ned. }\end{array}$ & $\begin{array}{l}\overbrace{\text { Uncl }} \\
\text { Bus. }\end{array}$ & $\begin{array}{l}\text { nued. } \\
\text { Lbs. }\end{array}$ & $\begin{array}{c}\text { Cle } \\
\text { Bus. }\end{array}$ & Libs. \\
\hline I Hard & 64 & 65 & 74.2 & 44.5 & 4 & 28 & 4 & 24 \\
\hline I $\quad "$ & 64 & 65 & 76 & 45.6 & 4 & 22 & 4 & I 8 \\
\hline I Northern & 65 & 65 & 74 & +4.4 & 4 & 24.5 & 4 & 24.5 \\
\hline$"$ & 65.5 & 66 & 77.6 & 46.6 & 4 & $r_{4}$ & 4 & I 2 \\
\hline “" & 62.5 & 64.5 & 76.3 & 45.8 & 4 & 25 & 4 & 17 \\
\hline$"$ & 61.5 & 63 & 74.9 & 44.9 & 4 & 28 & 4 & 22 \\
\hline$"$ & 62.5 & 63 & 74.3 & 44.6 & 4 & 25.5 & 4 & 23.5 \\
\hline No. 4 & 62.5 & 63 & $73 \cdot 3$ & +4.0 & 4 & 29.5 & 4 & 27 \\
\hline No. 4 & 60 & $6 \mathrm{I}$ & 74.5 & 447 & 4 & 27 & 4 & 23 \\
\hline No. 5 & 60 & $6 \mathrm{I}$ & 72 & +3.2 & 4 & 36 & 4 & 32 \\
\hline
\end{tabular}

The figures given in both this and the previous table represent the total yield of flour, as no attempt was made to separate the flour into different grades. It will be noticed that the percentage yield of flour given in Table II is higher than that shown in Table $I$, but that the variations in yield in one set of figures bear a somewhat similar relationship to those of the other.

It is particularly worthy of notice that while there is a decrease in yield of flour from the lowest grades, there is not that difference which might be expected, considering the wide range in the grading of the wheat. The two samples of No. 4 Northern gave flour slightly darker in color than the others, doubtless due to the fact that it is hard to grind frosted wheat without incorporating some of the wrinkled bran layers. The miller who did the grinding of the large lots stated that the color and yield of the flour from the frosted wheat could have been improved by steaming the wheat before grinding.

No complete chemical analysis was made of either the wheat or the flour, for it was thought that there would not be sufficient difference in the percentage amount of any of the constituents other than proteids to make the analysis of value. The chemical examination was therefore confined to the moisture, proteids and acidity of the flour:

The moisture and acidity were not determined in the flour of the crop of 1903. In the case of the 1904 crop, the moisture determinations were made at the time the other analytical work was done. It will be noticed that the second sample of No. 4 Northern contained a very high percentage of moisture, and, 


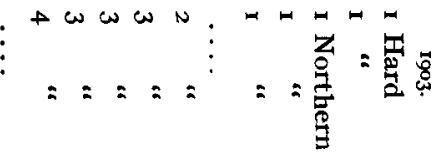

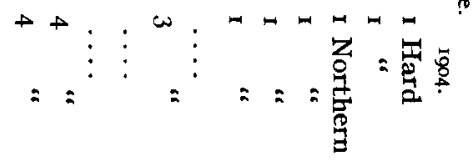

$$
\begin{aligned}
& \frac{\overbrace{0}^{\circ}}{8}
\end{aligned}
$$

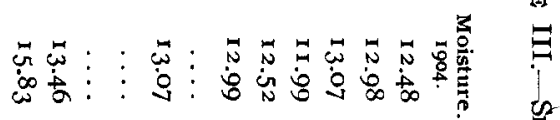

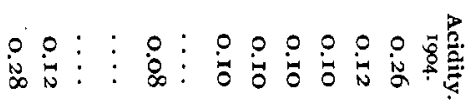

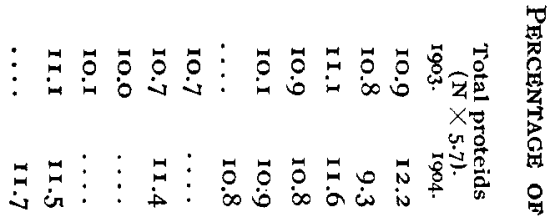

$$
\begin{aligned}
& \text { : } \\
& \text { 可高要 } \\
& \text { âa: }
\end{aligned}
$$

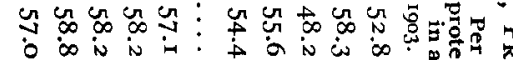

$$
\begin{aligned}
& \text { 3릉 } \\
& \text { 出 }
\end{aligned}
$$

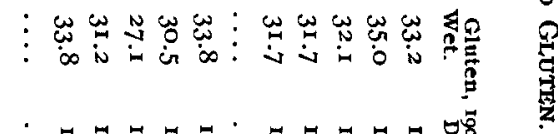

$$
\begin{aligned}
& \text { 紊 }
\end{aligned}
$$

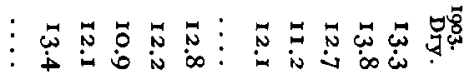

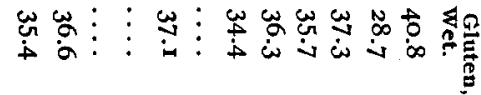

$$
\begin{aligned}
& \text { ڤ્山゙: }
\end{aligned}
$$


consequently, a high acidity. This flour was quite lumpy two months after it was made. It is quite possible that the wheat was damp when graded and that this fact influenced the Grain Inspector in placing it in a low grade. On the other hand, one sample of No. I Hard also contained a high percentage of acidity, and was lumpy, although the percentage of moisture was not high when the determination was made. Unfortunately, no determinations of moisture or acidity were made either in the wheat or flour at the time of grinding.

The percentage amounts of protein in the flour from the various grades of wheat of the 1903 crop are remarkably uniform, the extremes being 9.98 and II.I3. In the 1904 crop the extremes were 9.29 and I2.15. Recently attempts have been made to value wheat for flour purposes by the amount of protein present. ${ }^{1}$ It is evident that on this basis of comparison the extremes in quality occur in the two samples of No. I Hard of the crop of 1904. According to Prof. Snyder the protein content of a flour is only a general index of bread-making value, and that, provided the proteids do not fall below a certain minimum amount, the composition of the proteid material is of primary importance. ${ }^{2}$ Osborne and Voorhees, who have made a special study of the subject, state that gliadin and glutenin are the two principal wheat proteids and that these two substances form the gluten of the flour. ${ }^{3}$ Many attempts have been made to determine the ratio that gliadin should bear to glutenin to give the best results for bread-making purposes. The work done in this direction indicates that the gliadin-glutenin ratio varies considerably in wheat grown under similar conditions from year to year, and that these differences have been associated with only minor variations in the size of the loaf or general bread-making value of the flour. ${ }^{4}$ Snyder states that "the results available at the present time indicate that the percentage amount of gliadin (or proteids. soluble in 70 per cent. alcohol solution) in a flour is of more importance than the gliadin-glutenin ratio."

In view of the foregoing statements regarding the value of the percentage amount of protein and gliadin in forming an idea.

1 A. D. Hall: Journal Board of Agriculture, London, pp. 32 I-333.

2 Minn. Agr. Expt. Sta., Bull. 85.

"This Journal, I5, 47 I.

4 Ibid. 27, 9 . 
of the value of flour for bread-making purposes, a study of the data presented in Table III reveals the fact that, while there are variations in the amount of protein and gliadin in the various samples of flour, there is no decrease in the quantity which would indicate any falling off in the strength of the flour made from the lower grades of wheat. It is also noticeable that the gluten determinations point to the same conclusion.

For the purpose of obtaining fuller information regarding the nature of the protein content of these different flours, they were analyzed according to the method proposed by J. S. Chamberlain. ${ }^{1}$ The results are as follows:

Table IV.-Showing Per Cent. of Total Nitrogen and Per Cent, of Nitrogen in Form of Gliadin and Glutenin.

\begin{tabular}{|c|c|c|c|c|c|c|c|c|c|}
\hline Grade. & 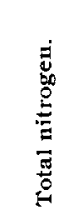 & 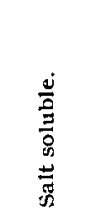 & $\begin{array}{l}\frac{0}{3} \\
\frac{3}{0} \\
\frac{0}{0} \\
\frac{0}{8} \\
\frac{8}{4}\end{array}$ & 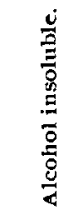 & 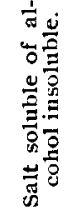 & $\frac{\text { J }}{3}$ & 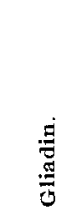 & 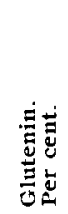 & 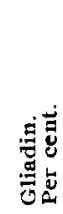 \\
\hline a Hard & $2.13^{\circ}$ & 0.403 & 1.024 & 1.106 & o.133 & 0.973 & 0.754 & 56.8 & 43.2 \\
\hline$" 1$ & 1.630 & 0.376 & 0.903 & 0.727 & 0.112 & 0.6 I 5 & 0.639 & 49.0 & 51.0 \\
\hline I Northern & 2.025 & 0.399 & I.197 & 0.828 & 0.091 & 0.737 & 0.889 & 49.4 & 54.6 \\
\hline " & 1.900 & 0.385 & I.057 & 0.843 & 0.102 & $0.74 \mathrm{I}$ & 0.774 & 49.0 & 51.0 \\
\hline “ & 1.925 & 0.533 & $\mathrm{I} .040$ & 0.885 & 0.112 & 0.773 & $0.5^{89}$ & 56.8 & 43.2 \\
\hline “ & 1.900 & 0.483 & I.04I & 0.859 & 0.134 & 0.725 & 0.692 & 51.1 & 48.9 \\
\hline " & 2.005 & 0.385 & $0.99 \mathrm{r}$ & 1.014 & 0.133 & $0.88 \mathrm{I}$ & 0.739 & 54.4 & 45.6 \\
\hline “ & 2.025 & 0.459 & I. I94 & $0.83 I$ & 0.133 & 0.698 & 0.868 & 44.6 & 55.4 \\
\hline “ & 2.060 & 0.329 & I. I 59 & 0.901 & O.I 37 & 0.764 & 0.967 & 44.2 & 55.8 \\
\hline
\end{tabular}

While this proposed method may not make a true separation of the gliadin and glutenin nitrogen, it does give a chance to see something of the gliadin-glutenin ratio. These results do not indicate that the flour from the lower grades of wheat is inferior to that from the wheat which graded very much higher. According to this method of valuation the wheat graded No. 4 Northern would be considered better than that of any of the preceding samples.

To further test the strength of the different flours, they were submitted to actual baking tests. The baking was done by a thoroughly competent man who used all his skill to bring out the best results from each flour. The plan adopted was as follows:

1 Proceedings of the 2oth Annual Convention of the Association of Official Agricultural Chemists. 
Six pounds of flour were weighed into a mixing pan and sufficient water, containing the salt and yeast, added to make a dough of medium firmness. Half a pound of flour was weighed into a separate dish to be used as required in making and handling the dough. That portion of the flour not required was weighed back, and from the total weight of flour used the yield of bread was calculated. The doughs were kept throughout at a uniform temperature, and the baking done in a large bake oven. In scoring the bread, the best loaf was credited with roo points, and the others graded to that. Three bakings were made of each flour. The average yield of bread from each flour and the average score of quality for both years will be found in Table V. The color of the bread was taken into consideration in allotting marks for quality:

Table V.-Showing Yreid of BrEad from Ioo Pounds of Flour and the QUALITY OF THE BREAD.

\begin{tabular}{|c|c|c|c|c|c|c|}
\hline & Grade & & $\begin{array}{l}\text { Yield } \\
\text { per IOo }\end{array}$ & $\begin{array}{l}\text { bread } \\
\text { of flour. }\end{array}$ & & \\
\hline & 903. & 1904. & & & 1903. & 1904. \\
\hline I & Hard & I Hard & I 42.5 & I 54.5 & 92.0 & 93.1 \\
\hline I & $"$ & I $\quad "$ & 146.4 & I 5 I. 5 & 95.0 & 94.0 \\
\hline I & Northern & I Northern & I 46.7 & 153.4 & 95.0 & 94.1 \\
\hline I & " & I & 144.8 & 153.9 & $9^{2.0}$ & 96.2 \\
\hline I & " & I & I 40,6 & I 55.2 & 95.0 & 96.1 \\
\hline & & I & $\cdots$ & I 54,8 & $\cdots$ & 98.0 \\
\hline 2 & “" & $\ldots$ & $\mathrm{I} 49.2$ & $\ldots$ & 90.0 & $\ldots$ \\
\hline 3 & $" 6$ & 3 & I 50.3 & I 54.0 & 100.0 & 92.2 \\
\hline 3 & $"$ & $\ldots$ & I 46.7 & $\ldots$ & 95.0 & $\ldots$ \\
\hline 3 & " & $\ldots$ & I 54.0 & $\ldots$ & 100.0 & $\ldots$ \\
\hline & & 4 & I 53.3 & I 56.8 & 80.0 & 90.2 \\
\hline & & 4 & $\ldots$ & I 54.3 & $\ldots$ & 90.2 \\
\hline
\end{tabular}

The bread from the 1904 wheat crop was weighed immediately on being taken from the oven, while that from the I 903 crop was weighed twenty-four hours after coming from the oven. This will account to some extent for the smaller yield of bread from the flour of that year.

In the IgO4 samples the quickest working dough was that from the first sample of No. 4 Northern. It also made the largest loaf, while that from the first sample of No. I Hard was the smallest. This, it will be noticed, corresponds with the strength of the flour as indicated by the gliadin content.

However, strength in flour is not the only point considered by miller and baker. To satisfy his customers the baker must 
produce a white loaf of bread, and, to do this, he must have white flour. As has been stated, the flour from the wheat graded No. 4 Northern was not equal in this respect to that from the higher grades. No figures were obtained that would bring out the differences in color, excepting that it was considered in allotting marks for quality in the bread. In fact, it was the chief cause for the lower marks given to the bread from the lower grades of wheat.

In general, the work here reported indicates that the milling, chemical and baking tests fail to bring out any very wide difference in the products of the individual lots of wheat studied. In yield of flour and in color of the bread the products of the lower grades are inferior, but in strength, as shown by the chemical analysis and in yield of bread, there appears to be little or no difference.

When we take into consideration the fact that the spread in price between No. I Hard and No. 4 Northern may amount to twenty-five or even forty cents per bushel, it would appear as though, in this case, the lower grades would not receive the price to which they were entitled, and, consequently, the farmer producing them would not receive justice. On the other hand, it is only fair to state that, according to our system of grading, many other samples graded down for other causes than being frosted may be much inferior in quality and thus reduce the standard of these lower grades. The price, however, is regulated by the quality of the grade as a whole and it may thus happen that individual lots are not paid for in their just merits.

ontario Agricuitural College, GUELPH, CANADA.

[CONTRIBUTION FROM THE BUREAU OF CHHMISTRY, U. S. DEPARTMENT OF AGRICULTURE, No. 60.]

\section{DETERMINATION OF MERCURY AND IODINE IN ANTI. SEPTIC SOAPS.}

BY ATHERTON SEIDELL.

Received November 23, 1905.

THE germicidal character of the halogen salts of mercury has been recognized for a number of years, and comparative experiments, as quoted by Sternberg, ${ }^{1}$ have shown that the iodide has 1 "Text Book of Bacteriology," 1896, p. I88. 